\title{
Reconstructing Governability: How Fisheries Are Made Governable
}

\author{
Andrew M. Song ${ }^{1,2}$, Jahn Petter Johnsen ${ }^{3}$, Tiffany H. Morrison ${ }^{1}$ \\ ${ }^{1}$ Australian Research Council Centre of Excellence for Coral Reef Studies, James Cook \\ University, Australia \\ ${ }^{2}$ WorldFish, Honiara, Solomon Islands \\ ${ }^{3}$ Norwegian College of Fishery Science, UiT The Arctic University of Norway, Troms $\varnothing$, \\ Norway
}

\begin{abstract}
Governability is an important concept in the political and environmental social sciences with increasing application to social-ecological systems such as fisheries. Indeed, governability analyses of fisheries and related systems such as marine protected areas have generated innovative ways to implement sustainability ideals. Yet, despite progress made, we argue that there remain limitations in current conceptions of governability that hinder further analytical development and use. By drawing on general systems theory - specifically cybernetics, control, and feedback - we interrogate the conceptual foundations that underpin two key limitations: the need to incorporate the numerous variables that comprise a complex, holistic system into a singular assessment of governability; and the a priori separation of the governor and the governed that precludes analysis of a self-governing situation. We argue that by highlighting the reciprocal nature of a governor-governed relationship and the co-produced understanding of governing capacity and objects, a relational approach to governability is possible. This offers a clearer and more pragmatic understanding of how governors and fishers can make fisheries governable.
\end{abstract}

Key words: Capacity; Cybernetics; Governance; Holism; Relationality; Social-Ecological System

\section{Introduction}

Governability is a composite concept that encompasses both instrumental capacity to govern and the quality of governing interventions in relation to certain standards and norms (Chuenpagdee \& Jentoft, 2015). The concept requires interdisciplinary understanding of natural system dynamics and socio-political characteristics and the interactions between them as a key premise for understanding and navigating natural resource governance (Berkes, Colding, \& Folke, 2008; Kooiman, Bavinck, Jentoft, \& Pullin, 2005; Pahl-Wostl, 2009). Thinking about a social-ecological system - whether a watershed, a marine reserve, or a 
fishery - in terms of how governable it is or how governable it can be, provides an intriguing notion that can potentially generate innovative ways to approach governance issues. In this article, we revisit the idea of governability in an effort to clarify its potential as an overarching analytical frame of reference for fisheries governance. In doing so, we also aim to contribute to an expansion of its theoretical purview.

More than simply referring to the condition of being 'controllable' or 'administrable', early development of the governability concept is most notably associated with Michel Foucault through his writings on government and governmentality in advanced liberal societies (Burchell, Gordon, \& Miller 1991; Lemke, 2007; Thompson, 2012). Recently, it has been described from the more focused viewpoint of natural resource governance - mainly, fisheries (Bavinck, Chuenpagdee, Jentoft, \& Kooiman, 2013; Jentoft 2007; Jentoft \& Chuenpagdee, 2015a; Johnsen, 2014; Kooiman et al., 2005; Song \& Chuenpagdee, 2010), with empirical applications also extending to other natural resource fields (e.g., biofuel industry- Di Lucia, 2013; forestry- Derkyi, Ros-Tonen, Kyereh, \& Dietz, 2013; animal husbandry- Löf, 2016; coastal zone management- Pittman, 2016). Insofar as fisheries governance is concerned, interest in governability has emerged from doubts about the efficacy of a state-dominated mode of governing characterized by command-and-control management. We have seen elements of this command-and-control management in many natural resource governance systems favouring the role of Weberian bureaucrats within centralized national bureaucracies (Bavington, 2002; Hardin, 1968; Holling \& Meffe, 1996). Such Hardin-inspired rationalist perspective is, however, criticized by contextualists inspired by Ostrom (1990) and others who identify diverse, bottom-up institutional elements to be crucial for resource governance (Anderies, Janssen, \& Ostrom, 2004; Jentoft, McCay, \& Wilson, 1998; Johnson, 2010). The contextualists leave behind the Leviathan and naïve rationalist ideal and embrace a shift to a society-centred account of governance which invites "a plethora of different schemes of self-government, public-private partnerships, collaborative efforts, policy entrepreneurs, and participatory initiatives" (Duit \& Galaz, 2008, p. 327). This shift is driven by the opinion that the state-governing model is becoming increasingly inadequate in mobilizing efficient and legitimate responses to the complexities of social-ecological problems. While the rationalist governing approach is rather narrow and founded on a simple understanding of linear and causal relationships within controllable and predictable systems, the 'governance' perspective is broader and more nuanced; it tries to bridge the nature-society gap by regarding the relationships to be governed as open, episodic and unstable, and by not solely focusing on rules and sanctions for governing, but on how governing evolves in rather complex and dynamic environments (Berkes et al., 2008; Folke, Hahn, Olsson, \& Norberg, 2005; Kooiman et al., 2005). Thus, it is concerned with what can be governed by governance and how capacity for governance can be built in ways that match social-ecological challenges, and therefore comprehensive "governability assessments" - a step-wise diagnostic framework for formulating a level of governability - would need to be carried out.

We see governability as a useful concept that can guide fisheries governance, but have seen through practice and from studying the literature that to undertake a governability assessment 
is an enormous task that seems never fully attainable. The noble aim of providing a holistic account of all possible governance characteristics and capacities through its many involved parts is extremely difficult. Furthermore, the reified distinction between those who govern and those being governed in governability assessment breaks down in the case of the governability of a self-governing entity, the blurred system boundaries of which pose a problem for the well-structured assessment rubric currently suggested (see Section 2). Such limitations suggest that there is room for further conceptual tinkering. What is at stake may be the basic notions of governance, such as the ontological position of a governing system with respect to a system-to-be-governed, the nature of an intervention-feedback relationship between them and subsequently what it means to have a governable system. Therefore, in this article we will re-examine governability and what it is about.

An alternative take on governability is to study the processes that construct the governance objects and capacity (Jessop, 1997). The governance objects are those entities described in the natural and social systems-to-be-governed (SG) that the interventions of the governing system (GS) are supposed to affect - e.g., fish, coral reefs, fishers as well as coastal and landbased activities. ${ }^{1}$ The governing interactions (GI) are about the (re-)shaping of these objects and capacity, such that governability will be related to how well the GS defines the objects and the SG enables the governance capacity. Like the rationalists and the contextualists, we are inspired by the systems theory and see governing and governance as cybernetic processes of intervention, control, responses, and feedback. ${ }^{2}$ Yet, this perspective is constructivist and relational in the sense that the interactions are constructing both those who govern and those being governed in the same process. While the rationalist approach with simple information and command-and-control relationship can be categorised as a first-order cybernetics, the contextualists have moved towards a second-order cybernetics, with coupled systems of complex relations that make it possible to think about designing governing interventions that fit specific system needs. We develop the contextualist approach into a higher-order cybernetics, where we see the interacting GS and SG as assembled by themselves through exchanges of information and power involving framing and consent. As this perspective focuses on mutual construction rather than designed fit or precise control, governability is an outcome that is continuously co-produced, always contingent and only temporarily stabilised. ${ }^{3}$ This article explores how this new perspective on governability characterizes the way governing takes place and suggests an alternative lens with which to study this process. The main question posed is then: Does a higher-order cybernetic approach on governance better explain how 'governability' becomes possible? In other words, does it allow a more analytically feasible way of understanding how governing is made achievable?

In the remainder of this article, the origin and the development of the governability concept is first outlined, followed by an explanation of the empirical and conceptual bottlenecks associated with the existing concept. After a brief introduction of cybernetics theory, we present three cybernetic orders and describe what they mean for fisheries governance and how they each promote different notions of governability. We then focus on the third-order inspired concept to detail two reciprocal mechanisms that lead to a co-construction of governability. The article concludes with a discussion of the potential that this narrower but 
more workable view of governability holds for enabling well-functioning fisheries governance.

\section{Governability thus far}

Governability was initially a loosely defined (and implicitly applied) term used in connection with theorizing broad-scale shifts in the governing landscape of the 1970s associated with globalization and the crisis of welfare state (see Burchell, et al. 1991; Janin, 2007; Lemke, 2007). Since then, a first major sharpening of the concept was delivered by Jan Kooiman, a Dutch political scientist, who studied governance as the changing socio-political interaction patterns between government and society which began to appear in the early 1980s (e.g., deregulation, decentralization, co-management, public-private partnerships and the growth of civil society) (Kooiman, 1993; Rhodes, 1996). He argued governability to be a permanent balancing act, or adjustment process, between governing needs on the one hand and governing capacities on the other (Kooiman, 1993). A more specific formulation by others has it pointing to the meaning of "governableness," which refers to being capable of being controlled or managed (Janin, 2007) or to "the possibility to intervene in a goal-directed way... by means of the instruments that are available to the central authorities" (Mayntz, 1993, p. 13).

Beginning in the early 2000s and couched in interactive governance theory, the idea received a renewed emphasis by a group of social and natural scientists interested in fisheries and aquatic resources issues (Bavinck et al., 2013; Kooiman 2008; Kooiman \& Chuenpagdee, 2005). The current formulation offers a two-dimensional characterization of governability that combines 'capacity' and 'quality' and envisages them as two perpendicular axes in a graph (Jentoft \& Chuenpagdee, 2015b). Here, capacity refers to the governing system's ability to respond to the challenges posed by the social-ecological environment (i.e., the systems-to-be-governed), while qualities are the norms and values which guide governance efforts. Jentoft and Chuenpagdee (2015b, p. 21) suggest that neither can be neglected, as "'good governance"” requires high scores on both axes." Hence, governability allows placing emphasis on both the governed and the governors, that is, it is possible to simultaneously consider "the aptitude of a group for being governed and the ways of governing this group" (Janin, 2007, p. 364). The concept also offers a strategic platform from which to combine instrumental and normative perspectives in governing as well as to bring together natural and social science expertise to jointly deliberate on governance.

\subsection{An empirical roadblock - the black hole of "holism"}

Notwithstanding these important advances, empirically, the current rendition of governability faces a significant setback. It sees governability as a way of making sense of the productive tension between capacity and needs. The greater the governing capacity, the greater likelihood that governability is boosted, that is, things become more governable. The more onerous the needs and properties of the defined social-ecological system are (i.e., highly 
complex, diverse, dynamic and scale-ridden), governability would likely be pushed lower, reducing the potential of the governing system to deliver on a stated promise. An impressionistic study comparing the governability of three coastal sectors - aquaculture, capture fisheries and coastal zone management, for example, suggested that governability is likely the highest for aquaculture because of the prevalence of a simpler form of socioeconomic organization (i.e., owner-operators) and mostly low for coastal zones due to the intricate overlap of many human activities and environmental processes (Chuenpagdee, Kooiman, \& Pullin, 2008). One way to improve governability is then to design the governing system to match the complexity of social-ecological system properties (Bavinck \& Salagrama, 2008; Cox, 2012; Scholtens \& Bavinck, 2013; Song, 2015a; Young 2002). Under this logic, governability too is posed as a property of the system - something that resides in the system, which is to be assessed and its higher value pursued. It follows that "the inherent and constructed characteristics of the system-to-be-governed ... the capacity of the governing system to address societal concerns ... and how the two systems interact" are all part of the essential information to be compiled (Chuenpagdee \& Jentoft 2015, p. 5). Accordingly, to fully estimate governability, one is required to examine each (unknown) aspect of subsystems according to a set of recommended criteria, such as the 'degree of wickedness', prevalence of system properties and 'goodness-of-fit' in a step-wise fashion (see Barragán Paladines \& Chuenpagdee, 2015; Chuenpagdee \& Jentoft, 2009, 2013), that is, through an all-encompassing and summative governability assessment framework, as shown in Table 1.

With such an extensive and composite framework for assessment, however, completing all steps to arrive at an overall governability of a system would constitute a herculean task. So far, existing assessment studies have focused on one or two steps or criteria to provide a partial view of governability (see Johnson \& Pálsson, 2015; other chapters in Jentoft \& Chuenpagdee, 2015a). To be sure, this empirical project can, and likely will, generate useful analytical insights, as specific questions can be targeted about the system - whether governance performance, governing images or structural misalignment. Yet, it will always be incomplete and lacking according to the noble aims of governability assessment. More crucially, even if one were to complete all the assessment stages, the current thinking has been silent on how to integrate or "sum" the findings from each assessment stage to arrive at the overall degree of governability in a meaningful way.

Table 1. Governability assessment framework (adapted from Chuenpagdee and Jentoft 2013)

\begin{tabular}{llll}
\hline Stage & Assessment targets & Features & Measures \\
\hline Stage 1 & Fisheries governance & $\begin{array}{l}\text { Degree of wickedness } \\
\text { of the problem }\end{array}$ & $\begin{array}{l}\text { Stakeholders' images } \\
\text { of the problem }\end{array}$ \\
& & $\begin{array}{l}\text { Existence of stopping } \\
\text { rules }\end{array}$ \\
& & The embedded nature \\
& & of the problem \\
& & Cost and reversibility \\
& & of prescribed solutions \\
\hline
\end{tabular}




\begin{tabular}{|c|c|c|c|}
\hline Stage 2 & $\begin{array}{l}\text { Natural and social } \\
\text { systems-to-be-governed, } \\
\text { the governing system and } \\
\text { the governing } \\
\text { interactions }\end{array}$ & $\begin{array}{l}\text { Prevalence of system } \\
\text { properties (i.e., in } \\
\text { terms of diversity, } \\
\text { complexity, dynamics } \\
\text { and scale) }\end{array}$ & $\begin{array}{l}\text { Components } \\
\text { Relationships } \\
\text { Interactions } \\
\text { Boundaries }\end{array}$ \\
\hline \multirow[t]{3}{*}{ Stage 3} & Governing system & $\begin{array}{l}\text { Goodness of fits of } \\
\text { elements (i.e., images, } \\
\text { instruments and } \\
\text { actions) }\end{array}$ & $\begin{array}{l}\text { Behaviour, decision, } \\
\text { mental models, } \\
\text { institutional } \\
\text { arrangements, } \\
\text { implementation }\end{array}$ \\
\hline & & $\begin{array}{l}\text { Responsiveness of } \\
\text { modes (i.e., self-, co- } \\
\text { and hierarchical) }\end{array}$ & $\begin{array}{l}\text { Awareness, learning, } \\
\text { sensitivity, conflicts }\end{array}$ \\
\hline & & $\begin{array}{l}\text { Performance of orders } \\
\text { (i.e., first, second and } \\
\text { meta) }\end{array}$ & $\begin{array}{l}\text { Consistency, } \\
\text { effectiveness, } \\
\text { transparency, justice }\end{array}$ \\
\hline \multirow[t]{2}{*}{ Stage 4} & Governing interactions & $\begin{array}{l}\text { Presence and quality of } \\
\text { interactions }\end{array}$ & $\begin{array}{l}\text { Information sharing, } \\
\text { co-learning, } \\
\text { adaptiveness }\end{array}$ \\
\hline & & $\begin{array}{l}\text { Enabling and } \\
\text { restrictive role of } \\
\text { power relations }\end{array}$ & $\begin{array}{l}\text { Inclusiveness, } \\
\text { representativeness, } \\
\text { participation }\end{array}$ \\
\hline
\end{tabular}

Scholars have observed similar difficulties in other system-based diagnostic schemes, such as the SES framework (Ostrom, 2009). Unpacking the complexity of a social-ecological system into a multi-tier set of variables has resulted in a tendency to seek an extensive list of attributes (e.g., surpassing 50 in Basurto, Gelcich, \& Ostrom, 2013). Even when only a handful of attributes are involved, obtaining a holistic and causal understanding of the systemic interactions followed by a diagnostic approach to assess problems and solutions can be an exceedingly arduous task (Agrawal, 2001; Cox, Arnold, \& Villamajor-Tomas, 2010; Cox, Villamayor-Tomas, \& Arnold, 2016; Hinkel, Cox, Schlüter, Binder, \& Falk, 2015). Although basing the assessment on appropriate theory should guide selection of the most pertinent attributes (e.g., as advised by McGinnis \& Ostrom, 2014), use of alternative theories could simply suggest different sets of attributes. Strictly speaking, this alludes to a paradoxical situation where an approach grounded in holism is never able to deliver a holistic picture. ${ }^{4}$ It is inherently limited to a partial diagnosis based on partial configurations of attributes for explaining sustainability outcomes. In this sense, the holism becomes a black hole.

\subsection{A conceptual roadblock - an analytical pitfall of pre-given categories}

The empirical difficulty is further complicated by an ontological tendency to reify the governing system and the system-to-be-governed as two discrete entities. Despite the 
acknowledgement that the systems concept only serves a "heuristic tool without any teleological, functional or reification connotations" (Kooiman, Bavinck, Chuenpagdee, Mahon, \& Pullin, 2008, p. 4), the current operationalization has made the GS, SG and the governing interactions (GI) the primary assessment targets and subsequently an empirical starting point (see Table 1). One has to, first, search for these sub-systems and establish their place in the analysis a priori, as Kooiman et al. (2008, p. 1) mentions: "the assessment of governability is approached by recognizing this whole to consist of three coherent analytical components." Categories are indispensable for making sense of the world around us.

However, to impose pre-given categories to a field before scholars can explore it can create not only artificial, but also false perceptions of difference (Jones, 2009). For example, if we study remote island communities, we cannot consider them as self-governing systems before we have explored actors, practices and institutions. It is after exploration we can decide who constitutes the governing system and the system-to-be-governed and sometimes see that they can essentially be the same entity. In such a case, the governing capacities of the GS and the needs of the SG would be difficult to distinguish and will develop together. Governability conceptualized as a "balancing act" between GS and SG, therefore, runs the risk of unduly reinscribing dualism in its analytical practice. In working with a well-defined set of variables, McGinnis and Ostrom (2014, p. 8) have identified a similar predicament in the SES framework with admission of no clear way out. They write,

.... a government organization, for example, might appear in two different top-tier categories of the SES framework, depending on the topic under consideration. When an analyst is concerned about the actions taken by the agents of that organization, attention should be directed to the Actors category, but attention should be directed to the Governance Systems category whenever it becomes necessary to explain the capabilities and responsibilities of that agent. By a similar logic, the norms that an actor considers relevant to his or her actions in a given setting can be treated as attributes of that actor, whereas the broader repertoire of norms available to individuals within the relevant social and cultural setting might best be interpreted as attributes of the governance system as a whole. We realize that not everyone will find this strict separation between structure and agency to be compelling, but it would be unreasonable to expect that any single representation can be equally satisfying for the full range of social scientists and policy analysts.

Despite the foreseeable merits of the current interpretation of governability, nagging issues in its conceptualization exist to limit its full potential as a productive means of analysis. Not unlike the SES framework, the preoccupation with pre-given system categories and stepwise, multi-variable assessment has persisted. Why so? Is there an alternative approach that fisheries scientists and policy analysts can use to bypass these limitations? To answer these, we need to understand what gave rise to this preoccupation in the first place. Here, we draw on cybernetic theory.

\section{Cybernetic orders}

As part of broader systems thinking, cybernetics is in many ways synonymous with complexity studies or systems sciences. It came to fruition as a holistic discipline in the $1950 \mathrm{~s}$ 
and 1960s, whose main concern lied with the "ubiquitous phenomena of control and communication, learning and adaptation, self-organization and evolution" (Scott, 2004, p. 1367). Analysts observed the application of control by negative feedback, for instance, in many domains including engineering, neurology, psychology, economics and anthropology. Provision of common concepts and terminology to facilitate connection between these different disciplines served a major motivation for the development of cybernetics (Scott, 2004). Moreover, its interdisciplinarity extends to both a social system as well as a biological one, and the study of the governance of human systems has been one of the discipline's traditional emphases from the outset (Rhodes, 1996; Scott, 2004).

\subsection{First and second-order cybernetics}

The initial model for cybernetics resembles a simplistic feedback-control paradigm associated with Newtonian mechanical objectivity. It refers to the positivist understanding of the world, which has a stable object observed by an externally positioned observer who peers into the system from an "objective" vantage point (Boxer \& Kenny, 1990), as characterized in Figure 1a. Here, interventions and feedbacks are not merely random but purposeful and teleological (Yolles \& Fink, 2015). This early cybernetic model assumes that the natural world is 'out there', whereby scientists could methodologically discover this truth, and the social system likewise is equally discoverable and can be neatly understood, planned, and governed.

As engagement between general systems theory and the social sciences increased in the late 1960s and early 1970s, it became evident that the first-order cybernetics paradigm was unsuitable to cope with the distinct tendency of the social system to self-steer and selfreference (Geyer \& van der Zouwen, 1991). ${ }^{5}$ Theorists realised that some rather drastic changes in cybernetics were necessary. Inspired by the biological metaphor of autopoiesis ${ }^{6}$, there was a clear recognition of self-organizing systems; that they are actor-oriented (whether individuals or organizations) and that different actors develop their own goals and try to realize them in interaction with their specific environment and other actors. Furthermore, self-fulfilling or self-defeating prophecies occur in the social world embedded through feedback loops, creating a self-perpetuating situation that is difficult to manoeuvre or overturn (Geyer \& van der Zouwen, 1991). These revelations pointed to the inherent unpredictability (and complexity) which a simple control paradigm cannot adequately contain, such that the truly self-organizing systems "will always expand beyond the frames of reference adopted by observers to model their behaviour" (Scott, 2004, p. 1370).

Representing the second-order cybernetics (also known as social cybernetics, sociocybernetics, or social systems theory), this new trend brought with it two major effects.

First, given that a system cannot be steered from the outside, the second-order cybernetics establishes a new ontological frame that positions the observer as part of the system under investigation, as shown in Figure 1b. Feedback and feedforward loops couple the objects (SG) and the observer (GS), and together they form "a learning machine, being controlled through adaptive processes" (Yolles \& Fink 2015, p. 301). Secondly, observations are no longer a direct representation of a reality. Realist assumptions about external, objective 
knowledge cease to hold, as knowledge becomes subjective and observer-dependent conditioned by the observer's inner cognitive processes (Geyer \& van der Zouwen, 1991). Context and reflexivity are the norm in this regard. Figuratively, von Foerster invites the observer of systems to "enter the domain of his own descriptions and accept the responsibility for being in the world" (Scott, 2004, p. 1372-1373).

(a)

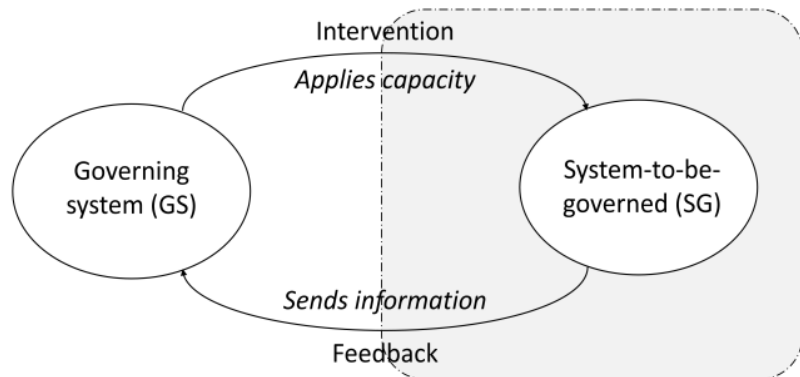

(b)

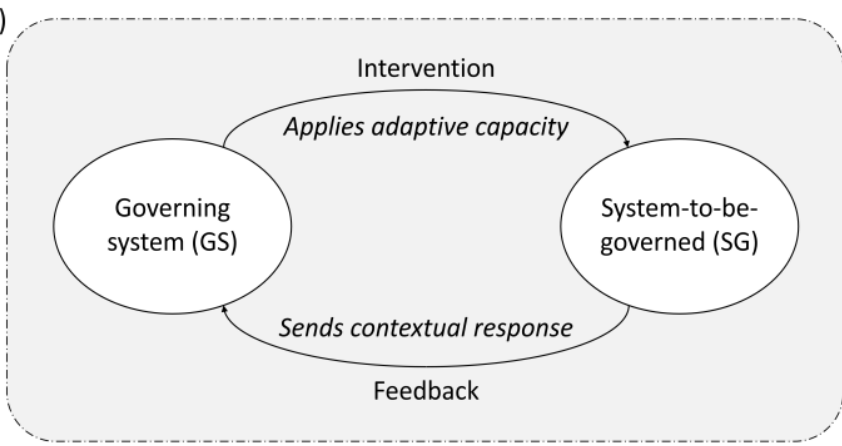

(c)

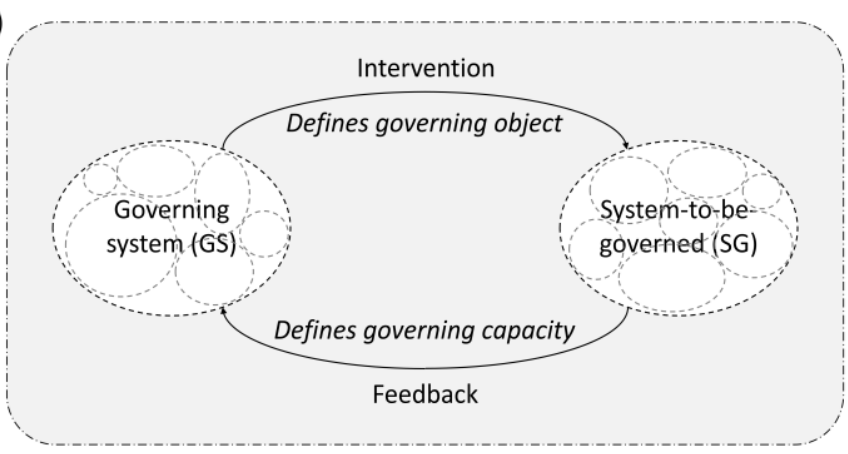

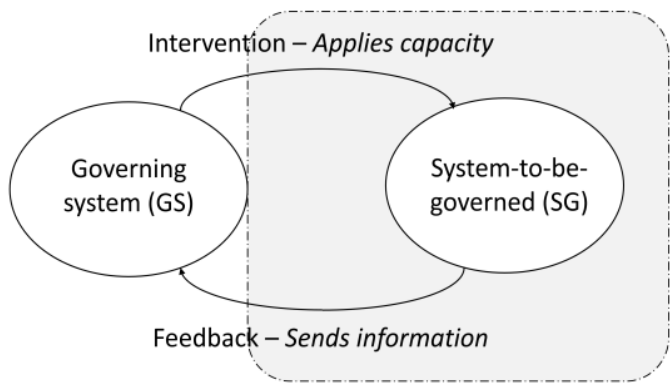

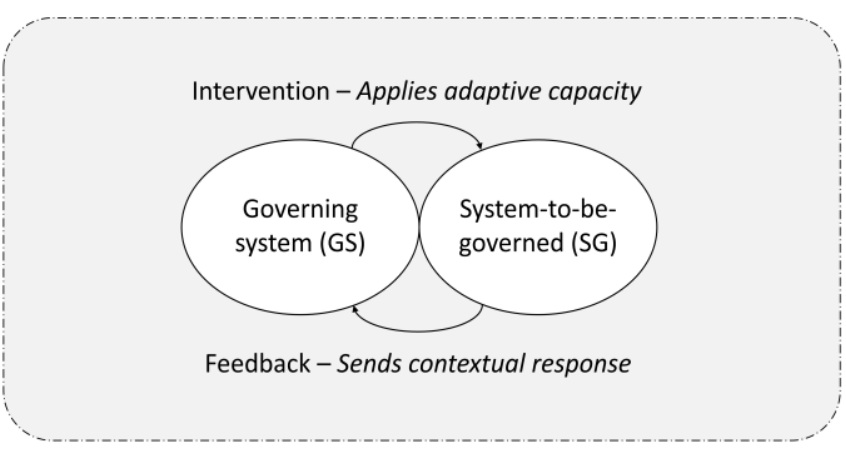

Intervention - Defines governing object

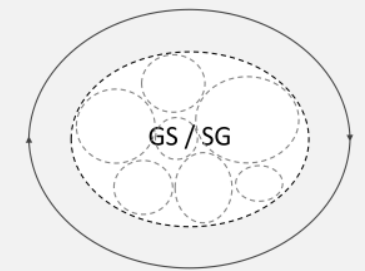

Feedback - Defines governing capacity

Figure 1. Governance model according to three cybernetic orders (a) first-order; (b) secondorder; (c) third-order. Figures on the left-hand side represents a status quo, while those on the right-hand side shows an idealized state of the system when the system is supposedly most governable. On the right-hand side, the differences in the overlap of GS and SG stem from the assumed system ontology of each (i.e., $1^{\text {st }}$ order - impeccable control; $2^{\text {nd }}$ order seamless fit; $3^{\text {rd }}$ order - coherent assembly). For each figure, shaded area denotes a bounded system. 


\subsection{Third-order cybernetics}

While the second-order establishes a coupled ontology, the third-order describes the system through a relativistic worldview in which the observer and the observed co-construct "truths" about each other and their fate (see Figure 1c). This relativistic frame is significant because of its ability to curb the privileging of the observer's viewpoint which inadvertently occurs in the second-order dynamics. Boxer and Kenny (1990, p. 206) write that, by way of pursuing all-encompassing vision of the system being described, the observer "came to believe his vision of the second-order domain to be a domain of meta-observation", where one obtains a panoptic overview. Here, the "seductive" reward for all the effort the observer had made in order to overhaul the conventional understanding of reality is to see himself/herself transcending the domain of ordinary mortal observers and achieving the holistic perspective (Boxer \& Kenny, 1990). Yet, such a privileged position contradicts the very epistemology of unknowable 'reality' and unattainable 'ultimate perspective' upon which the second-order is founded. It effectively risks collapsing the second-order domain of descriptions back into the domain of the first-order.

In bypassing this dilemma, third-order cybernetics offers a stronger constructivist outlook (c.f., Berger \& Luckmann, 1966). Also drawing on relativism (Barnes \& Bloor, 1982) and the 'relational' approach (Jessop, 1997), the emphasis is on the co-production of governing objectives, capacity, knowledge and meanings, with which the observer and the observed come to be defined and assembled. Less concerned with coming to grips with the complexities of the system and how they match up in their interactions, analytical rigor now rests on being able to elucidate how a system is affected or re-made by each other and what this means for shared or converging contexts and ethics. Such an approach is reciprocal, reflexive and even somewhat more radical than that which the earlier order cybernetics have envisioned (see also Section 4.2).

In sum, according to the first-order cybernetics, a governor conducts intervention on an external target and pursues external feedback loops (e.g., a government fisheries extension officer instructing fishers and evaluating results). When it is deemed most governable, the governor may move in close, but still remains outside of the system reality (Figure 1a). Second-order cybernetics is concerned with negotiating system complexity and unpredictability through the internal recursive feedback loops within a bounded selforganising system (e.g., an extension officer delivering a program with fisher participation and contextual understanding). Here, the ideally functioning system would have the GS and the SG in its best-fit configuration positioning them side-by-side (Figure 1b). Finally, the third-order cybernetics signifies the domain where the interventions and responses are interlinked in a way that it only becomes meaningful to describe them relationally, i.e., one cannot fully understand oneself without the consideration of the other (e.g., an extension officer learning to master the extension material only through interacting with fishers). The most ideal governability scenario from this perspective would be the GS and SG cohering to form more or less the same entity. 


\section{Recasting governability}

4.1. Natural resource governance in light of cybernetic orders

The development of governance ideal and practice has paralleled the progression of cybernetics from the first- to second-order (see also Table 2). Scholars refer to the conventional mode of governing natural resources including fisheries as "command-andcontrol" or "top-down", which consists of identifying a problem (e.g., a disruption in ecosystem services) and implementing a solution to control it. Pelosi, Goulard, and Balent (2010, p. 460) saw that "this type of management tends to make SES vulnerable because it ignores the interactions between biophysical and social systems." There are numerous examples of the first-order-infused governing model that has produced perverse outcomes in the administration of fishery resources (e.g., Acheson, 2006; Bavington, 2010; McGoodwin, 1990). Similarly, the "panacea problem" or a blueprint approach, in which fisheries scientists and policy analysts prescribe overly simplified solutions for a wide range of problems, is misguided precisely because it does not take into account system complexity. According to Ostrom and Cox (2010, p. 452), the result is "a lack of fit between programmes and their supposed social-ecological targets". What many of these scholars advocate instead is to build a general diagnostic model to conduct rigorous research and policy analysis and to prescribe necessary reforms (e.g., Andrew et al., 2007). Such an approach finds its basis in the secondorder cybernetics where coupled interactions, agency and vulnerability, contested norms and knowledge, adaptive learning and contextual details are given due consideration in understanding system dynamics and effects. Resource governance paradigms that are becoming dominant in recent years, such as interactive governance (Kooiman et al., 2005), adaptive co-management (Armitage, Marschke, \& Plummer, 2008), and resilience (Berkes et al., 2008), are arguably a part of this second-order thinking. Most broadly, the second-order cybernetics signals the transition from governing to governance, which acknowledges the multiplicity of interdependent actors with interwoven responsibilities and their diversifying forms of action, intervention and control (Rhodes, 1996).

What would a governance approach inspired by third-order cybernetics emphasize then? A different type of feedback loop would occur, in which emphasis is on "merging", or an assemblage, of actor groups (whether the governing, social or ecological components). This goes beyond "linking" through fit or networks, which assumes that actors maintain their discrete identities. This new perspective would be about approaching the governing of systems with recognition that one's action and conditions can only be meaningfully understood and acted upon by relating them to another's responses, practices and their normative foundations. In other words, governors' capacity, power and success are never of their own making, but enabled only as much as the social-ecological system allows it. In the same vein, a social-ecological system's performance also does not take place independent of the governing system's vision, definition, and evaluation metric (see Section 4.2 below). Because of this relationality, there will always be a tension in which systems or groups of actors come first and matter most in governing. What is the dependent and what is the independent variable also becomes less obvious in analysis. 
Table 2. Conceptual underpinning of the three cybernetic orders and their rendering of governability

\begin{tabular}{|c|c|c|c|}
\hline & First order & Second order & Third order \\
\hline $\begin{array}{l}\text { Underlying } \\
\text { epistemology }\end{array}$ & Positivist realism & $\begin{array}{l}\text { Critical realism, } \\
\text { contextualism, post- } \\
\text { normal science }\end{array}$ & $\begin{array}{l}\text { Social } \\
\text { constructivism, } \\
\text { relativism, } \\
\text { interpretivism }\end{array}$ \\
\hline $\begin{array}{l}\text { System } \\
\text { characteristics }\end{array}$ & $\begin{array}{l}\text { Constant, efficient, } \\
\text { predictable }\end{array}$ & $\begin{array}{l}\text { Complex, } \\
\text { unpredictable, } \\
\text { negotiable, scale- } \\
\text { dependent }\end{array}$ & $\begin{array}{l}\text { Situationally } \\
\text { emergent, relational, } \\
\text { provisional, } \\
\text { reciprocal }\end{array}$ \\
\hline $\begin{array}{l}\text { Governability } \\
\text { definition }\end{array}$ & $\begin{array}{l}\text { Stable application of } \\
\text { measured } \\
\text { intervention and } \\
\text { reliable feedback } \\
\text { that places target } \\
\text { system within } \\
\text { prescribed thresholds }\end{array}$ & $\begin{array}{l}\text { Dynamic } \\
\text { correspondence of } \\
\text { structural and } \\
\text { functional } \\
\text { components of } \\
\text { system properties } \\
\text { and governance } \\
\text { capacity }\end{array}$ & $\begin{array}{l}\text { Temporary } \\
\text { stabilization of the } \\
\text { symbolic } \\
\text { representation of } \\
\text { relations through } \\
\text { reciprocal defining } \\
\text { of capacity and } \\
\text { objects }\end{array}$ \\
\hline $\begin{array}{l}\text { Preferred } \\
\text { governance } \\
\text { configurations } \\
\text { (an example in } \\
\text { fishery) }\end{array}$ & $\begin{array}{l}\text { Command-and- } \\
\text { control, rules and } \\
\text { regulations (e.g., } \\
\text { fishing quota and } \\
\text { total allowable } \\
\text { catch) }\end{array}$ & $\begin{array}{l}\text { Adaptive and } \\
\text { interactive } \\
\text { management, social } \\
\text { learning and } \\
\text { stakeholder } \\
\text { engagement (e.g., } \\
\text { ecosystem-based } \\
\text { management) }\end{array}$ & $\begin{array}{l}\text { Relationally } \\
\text { congruent, little } \\
\text { distinction of } \\
\text { governors and those } \\
\text { being governed } \\
\text { (e.g., community- } \\
\text { based management) }\end{array}$ \\
\hline $\begin{array}{l}\text { Proxies for } \\
\text { governability }\end{array}$ & $\begin{array}{l}\text { Steady state, market } \\
\text { equilibrium, } \\
\text { Maximum } \\
\text { Sustainable Yield, } \\
\text { Carrying Capacity }\end{array}$ & $\begin{array}{l}\text { Adaptive capacity, } \\
\text { collective action, } \\
\text { self-organization }\end{array}$ & $\begin{array}{l}\text { Goals, discourses, } \\
\text { practices and } \\
\text { configurations } \\
\text { coming to a coherent } \\
\text { assemblage }\end{array}$ \\
\hline $\begin{array}{l}\text { Governability in } \\
\text { ideal state }\end{array}$ & "Impeccable control" & "Seamless fit" & "Coherent assembly" \\
\hline Risks & $\begin{array}{l}\text { Assumption that } \\
\text { everything is } \\
\text { governable (e.g., the } \\
\text { blueprint and } \\
\text { panacea approaches) }\end{array}$ & $\begin{array}{l}\text { Always requires } \\
\text { more knowledge of } \\
\text { the parts and the } \\
\text { system; There are } \\
\text { limits to } \\
\text { governability given } \\
\text { the complexity }\end{array}$ & $\begin{array}{l}\text { Less normative and } \\
\text { prescriptive, thus } \\
\text { weak on generating } \\
\text { policy } \\
\text { recommendations } \\
\text { and is harder to pin } \\
\text { down }\end{array}$ \\
\hline
\end{tabular}


This idea of governance would be most akin to the "intersubjective resilience narrative" described in related literature (see Powell, Larsen, \& van Bommel, 2014, p. 146), in which a shift of emphasis is suggested "from the assumption of distinct entities coming to the table and articulating differences and interests to the concrete and ongoing process of the enactment of realities" through engagement in joint tasks and praxis. The process for learning would not be simply adaptive but also transformative (e.g., triple-loop learning, see PahlWostl, 2009). It is not sufficient to just focus on accumulating what we do not know - e.g., new knowledge about system properties, but also letting go of what we already know and might feel sure of (Boxer \& Kenny, 1990), such that we can allow ourselves to be re-made in terms of who we are and what our role is in governance. The subsequent sections explore what governability informed by a higher-order cybernetics may look like and the analytical potential it offers. In doing so, we present a re-defined notion of governability.

\subsection{Higher-order governability}

To begin, the way the third-order governability approaches the system concept (and its ontology) is not entirely incongruent with the second-order, in that the distinction between the GS and the SG is only maintained for heuristic purposes assisting with an overall cognition and management of the world. The main difference, however, is that instead of starting with pre-selected categories for the purpose of charting a comprehensive knowledge structure and teasing out holistic connections (as in the case of a diagnostic assessment), the third-order perspective would start very modest from the descriptions of governing interventions (i.e., actions and instruments), the effects of them and what their objectives are. It is from these practices we can deduce the images, the capacities, and the conceptions of the SG (as a set of governing objects) and the GS (as procedures and institutions involved). While general categories of groups (e.g., government agency, fishing community and scientific circle) would still be adopted in the analysis, because 'system fit' is no longer the primary angle with which to analyse governance, the assumption of discretely bounded entities and their finely segregated variables become less pertinent. Rather, as described by Johnsen, Sinclair, Holm, and Bavington (2009), systems are approached as a symbolic representation of relations to which a set of interventions and feedbacks are supposed to interdepend. The bounding and assembling process itself, which is contingent and ongoing, becomes the focus rather than its compartmentalized outcome as a particular category (sensu Jones, 2009; Li, 2007). Hence, system distinction always remains inchoate - partially formed and incomplete.

\subsubsection{How governing capacity is derived}

First, the third-order cybernetic viewpoint still has that governing is initiated through interventions and feedbacks as part of the overall system. The actors in the governing system attempt to govern through programs, measures and instruments; it is what governors do. They are in the business of attempting to steer the conduct of other actors and the conditions of the system-to-be-governed. The potential success of a governing intervention, however, cannot be guaranteed by enhancing the governing system's capacity alone, because what 
presupposes a lasting success, or a transformative change, is how the system-to-be-governed (both natural and social components) 'receives' the intervention and 'responds' to it in reflection of its internal logic and inertia. These "tendencies" of the system-to-be-governed will ultimately dictate whether an intervention was a meaningful one and is of value to the overall society. For example, according to Blaikie (2006), community-based natural resource management (CBNRM) is often a failure because excitement is only generated within senior government officials and other external groups such as donor agencies and non-governmental organizations, but not target communities themselves. The performance of CBNRM is decided by "the interests of different actors, both within political elites and in civil society, [who] will shape the strategy of acceptance followed by active implementation, acquiescence, rhetorical gestures, or foot-dragging" (ibid, p. 1951). Further, he notes cases where local people have only benefited when the government came to relinquish its professional and economic capacity. What is more, despite the continual call to increase investments, inadequacies in the human and financial capacity of national governments have persisted hindering the performance of government-initiated programs, as a recent global-level study of marine protected area effectiveness has also confirmed (Gill et al., 2017). In our view, these stories expose the deficiency of exclusive capacity-based thinking in government steering. They help sustain a doubt as to the efficacy of solely concentrating on bettering government's action potential as well as on placing governors in the privileged position to judge what and how governing needs to take place.

The position being offered in this paper, with emphasis on the SG, finds support in Bruno Latour's exposition of power, in which a successful command results not from a reservoir of power accumulated in governors (i.e., how "powerful" they are), but is made from the actions and wills of those being governed, who actively shape or change the command in many different ways to achieve their unique goals (i.e., a command is "translated" in accordance with his/her own projects, Latour, 1986, p. 264). This view is further packaged as a paradox: "when an actor simply has power nothing happens and s/he is powerless; when, on the other hand, an actor exerts power it is others who perform the action" (ibid, p. 264). In other words, no matter how much power one appears to accumulate (as a quantitative phenomenon, Hindess, 1996), it remains an illusion; power is something that becomes evident only in the aftermath of being conformed to. Therefore, he points out that power must be treated as a consequence rather than as a property that causes action.

We argue that governing capacity works in a similar manner. Deriving capacity ultimately relies on the compromise, consent or submission of those over whom the governing intervention is exercised. It is not something that can be readily stored up and dispensed at will to create an effect on a social-ecological system. Instead, it is obtained only a posteriori after the target system had a chance to interact and formulate a reaction. Hence, SG defines whether GS is capable or not and in what ways. Capacity becomes a contingent outcome based on these relations. 


\subsubsection{How governance object is defined}

Secondly, being governable also means GS having a part in constructing what it is dealing with. This relation goes beyond acquiring an understanding of what the GS faces within the SG and how to adapt, but also recognizing its role in forming the very objects it tries to govern. It is about building a representation of the reality in ways that suit the intervention desires of the GS with an ultimate aim of shaping the conduct of target groups according to that version of reality. Through the framing of knowledge, the delineation of concepts and the specification of objects and boundaries, it involves defining a discursive field in which governing interventions are justified (Lemke, 2007). This is in fact analogous to what Rittel and Webber (1973, p. 162) identified in "wicked problems" in planning when they deduced "one cannot meaningfully search for information without the orientation of a solution concept; one cannot first understand, then solve." Couched in systems thinking, they were unequivocal that when a governing intervention is conceived, this invariably means that an accompanying end outcome is also conceived by the GS (e.g., what SG should look like). Hence, understanding the particular representation of the SG as imagined by the GS, and governing techniques employed to reinforce it, would be key to making sense of the SG itself.

For instance, instituting quota-based fisheries has precipitated changes in both the fishing sector and the relevant communities, as well as in the perceptions of relations between fish and society (Carothers \& Chambers, 2012; Johnsen \& Jentoft, 2018; Johnsen, Murray \& Neis, 2009; Pinkerton \& Davis, 2015). The newly introduced procedures such as more stringent license requirement and trading of quotas arguably stem from an effort to recharacterize the fishery system, towards one that favours an efficiency-driven, neoliberal outlook that has pervaded many government fisheries departments and policies around the world since the 1970s. Here, governors's vision of fishers is one of entrepreneurs engaged on full-time basis and who professionally manages their capital, time, crew and sale of catch for individual fishing success.

Likewise, fishing and community spaces can also be made 'legible' (sensu Scott, 1998) by producing a simpler representation of the often complex and indistinct social-ecological patterns. Through strategies such as spatial planning, zoning schemes and census as well as setting up local-level fisher organizations, a new context is created for the SG, upon which governing interventions can be based. Once a new model is introduced, the degree to which the systems are made governable would depend on the willingness of those being governed to accept the new representation and to self-regulate themselves to suit that model. Foucauldian governmentality is helpful in this sense (Dean, 1999; Foucault, 1991; Johnsen, 2017; Song, $2015 b$ ); it is enabled by subtle but crafty deployments of governing instruments and rhetoric in a way that affected citizens assume the governing influences as their own and start to practice and even defend them as the co-governor. When successful, this brings their conducts and mentality into alignment with the governing aims and produces new governable relations. In the Norwegian example of quota-based fisheries, Johnsen (2014) has detailed the making of new subjectivities in the remaining fishers who have over time come to accept the 
new practices prescribed for them - which were in large part induced by technical and symbolic governing devices rather than by overt regulations or moral policing (i.e., command-and-control).

From this perspective, the social-ecological system is not only the constructor of the governing system's capacity to govern, but also a construct that the governing system recreates as a governance object. With this interdependence between gaining of the capacity and defining of the objects in continual flux, attaining governability would imply a temporary stabilization of the new relations among those involved in governance. When we recognize that this is happening, we might say that the system is governable.

\section{Practising the new governability lens}

As we have illustrated, a governability concept promoted in the literature thus far, with its basis in the second-order cybernetic narrative, has advantages compared to the earlier firstorder thinking, but still remains burdened with significant limitations owing to its ontological and epistemological underpinnings. Promotion of coupled interactions assumes that there are separable entities. Further, system boundaries that distinguish the SG from the GS have been bolstered in analyses, posing difficulty in addressing situations that feature blurrier interfaces, including an idealized case of self-governance as well as a common instance of a governance participant 'wearing multiple hats'. In addition, preoccupation with achieving fit among the many salient system properties through processes of adaptation and attunement, in our opinion, has made governability assessment itself a "wicked" task that is unlikely to be ever achieved in its entirety. Inspired by a third-order cybernetic approach, we propose that it might be useful to recast governability as an outcome of reciprocal relations rather than a system property indicative of the level of systemic interactions. Studies of this reimagined governability would centre on peering into the representations of consent or compromise as well as the definitional power of governing instruments, as could be gleaned from discourses and practices.

It is useful to distinguish between the analytical third-order cybernetic approach that expands the way we imagine and study governability and the actual organisation of governance systems that follows the third-order style of governing. We do not suggest that governance always needs to be organised as a third-order kind (e.g., self-governance). Some fisheries, for instance, might sufficiently thrive under the direct management of the central government, enabled by efficient regulatory control and precise social-ecological feedback from industry participants. Individual fishing quotas based on total allowable catch is one form of government policy that seeks an economically rational means to a sustainable resource harvest, and has at times produced results that can be considered governable under the purview of the first-order cybernetics (e.g., see Andersen, Andersen, \& Frost, 2010; Annala, 1996; Johnson \& Pálsson, 2015). The important point is that any choice of governance configuration, regardless of its order, will cause relational changes that have to be taken into account when the system is studied. To understand how a first-order-based system re-orders 
the natural and institutional environment and how that in turn affects its own legitimacy will require a third-order analysis. A contextualist and complexity-driven approach such as ecosystem-based management can also bring about governable effects on the system (e.g., see Christie et al., 2009; Morrison, 2017; Olsson, Folke, \& Hughes, 2008). But again, to understand how this new frame succeeds in re-characterizing fishing communities, practices and spaces and how the ecological processes and stakeholder interests come to support the changed relations, a third-order logic will need to be employed. Our view, therefore, is that a governability analysis inspired by the third-order cybernetics can be applied to study all situations of governing ${ }^{7}$, because of the inherently reciprocal disposition of any governorgoverned relationship. Such an attempt would help generate a different set of insights into how a system becomes or remains (un)governable. This possibility is presented in Box 1 .

Box 1. A summarized example of third-order governability analysis

Kelp harvesting in Iroise Sea, France: Frangoudes and Garineaud (2015) have documented how the natural, social and governance systems of small-scale kelp harvesting in Brittany have interacted and evolved over time in a state of co-production. The authors state that the natural system-to-be-governed can be clearly considered part of a social construct, with its representation modified from initially one species of commercially-viable kelp to two species, also bringing with it an incorporation of a wider range of biodiversity concerns. This definitional shift has been facilitated by an integration of scientific knowledge on kelp species, end product development and harvesting and processing innovations. New possibilities afforded by these techniques then in part remoulded the socio-economic practices of the harvesters regarding their operational patterns, fisher organization and gender roles. Changes in the governance system - the strengthening and dissolution of various organizations such as the inter-professional committee, local and regional fisheries committees and a processing industry organization - also appear intricately influenced by the developments in other systems. Most recently in 2007, to protect the natural and architectural heritage of the area, a marine protected area was created with an introduction of a marine park authority (PNMI), which, according to the authors, resulted in enhancing the governability of the whole system. On the one hand, the capacity of the PNMI has been upheld because, despite lacking regulatory power, it has acted as a forum in which all users meet and discuss issues related to the marine area and its future. By being sensitive to the economic needs of the harvesters in addition to the conservation aims, it has secured the acceptance of many kelp harvesters. On the other hand, such support has allowed the PNMI to employ various management techniques (in turn, further securing the conservationoriented view of governance) - for instance, research on the location of kelp forests and the abundance of biomass in the area contributed to formulation of management rules for one of the species; and the introduction of a Vessel Monitoring System facilitated the allocation of a specific harvesting zone to each boat. The authors conclude that the present governance situation, based on close collaboration and stable relations between the fishers, the park authority and the industry, is a governable one, which (for now) preserves the potential of extending the 50-year-long history of resource abundance and sustainable exploitation into the future. 


\section{Conclusion}

In sum, in first-order cybernetics, the belief is that everything can be governed in the same way, but with large demands on resources and administrative oversight to maintain precise control. In second-order cybernetics, to govern is to design a governing system that fits the intricate and dynamic details of a system-to-be-governed. Through a holistic overview of various attributes and their interactions, second-order efforts strive to assess the level of governability featured in the system, and aspects for improvement. In this case, governability holds a somewhat pessimistic tone, because in search of a comprehensive understanding, nothing ever seems very governable. Our examination of governability that draws on the third-order cybernetics turns it around and asks how governing is enabled by the system-tobe-governed and simultaneously how governing reconstructs the world. Governing interventions, which many fisheries scientists and policy analysts normally view as regulatory tools, are actually instruments for conceptual and relational change. They do not regulate relations but they change them, with unforeseen consequences. Therefore, what we have learned from the exploration of the third-order approach is that this is not a question about more and more detailed and comprehensive knowledge, but a question about defining governance objects that come to be accepted. From this point of view, governability will be an effect of a successful assemblage of actor relations around a defined and agreed upon governance object. We admit that our perspective reduces governability to a narrower, less holistic issue, but conversely it also becomes more feasible to apply without assessing the whole universe. Ultimately, it nudges us to the understanding of how governability becomes achievable, that is, to gain an insight into the process through which governors and the governed simultaneously create governable systems.

Appreciating the co-constructed nature of governance encourages a view of governability that is neither mechanistically simple nor contextually bewildering, but calls for a notion that supports the fostering of a relational outlook. It is our hope that this expansion of what governability represents can trigger new opportunities in informing the progress of fisheries governance and its intended outcomes.

\section{Notes}

${ }^{1}$ The governing system (GS) typically denotes the various levels of government mandated to manage fisheries with all associated procedures and institutions but it can also include nongovernmental or supranational organizations as well as informal community groups that exercise authority and seek legitimacy.

${ }^{2}$ Cybernetics can be referred to as a transdisciplinary scientific study of control and communication in both inanimate objects and living organisms.

${ }^{3}$ Our use of 'co-production' is inspired by Jasanoff and other science and technology studies scholars' meaning of the term, e.g., "the ways in which we know and represent the world (both nature and society) are inseparable from the ways in which we choose to live in it" (Jasanoff, 2004, p. 2). We draw on this notion to support our view that governing and being 
governed are inseparable and mutually constitutive of each other. "Co-" here verges on meaning 'simultaneously' rather than 'collaboratively'.

${ }^{4}$ Powell et al. (2014) makes a similar argument about the resilience narrative running the risk of bolstering the traditional sectoral and hierarchical governance structures which they set out to revolt against, owing in part to its reliance on "expert-driven system targets."

${ }^{5}$ Not all of modern society exhibits or seeks a tendency for self-steering, however. Geyer and van der Zouwen (1991) notes that the classical control paradigm can offer a meaningful analytical frame for understanding and improving the steering processes of enterprises such as hospitals and universities.

${ }^{6}$ In social terms, Yolles and Fink (2015, p. 301) describe autopoiesis as "a network of processes through which strong anticipation is facilitated. It enables a system to define its own boundaries relative to its environment, develop its own code of operations, implement its own programmes, reproduce its own elements in a closed circuit, live according to its own dominant paradigms and have operations that cannot be controlled from outside its boundaries.

${ }^{7}$ So far we have argued that the third-order cybernetic analysis can be used to find ways to improve governability in particular case studies. How it can be set up to allow a comparison of different governance systems is a topic of continuing discussion.

\section{Acknowledgements}

This work was supported by the ACIAR-funded project "Improving community-based fisheries management in Pacific island countries" (FIS/2012/074). Authors thank Yasa Belmar, Philippa Cohen, Vera Horigue, Derek Johnson, Joeri Scholtens and two anonymous reviewers for constructive and helpful comments on earlier versions of the manuscript. This work is a contribution to the CGIAR Research Program on Fish Agri-Food Systems (FISH).

\section{References}

Acheson, J.M. (2006). Institutional failure in resource management. Annual Review of Anthropology, 35, 117-134.

Agrawal, A. (2001). Common property institutions and sustainable governance of resources. World Development, 29, 1649-1672.

Anderies, J.M., Janssen, M.A., \& Ostrom, E. (2004). A framework to analyze the robustness of social-ecological systems from an institutional perspective. Ecology and Society, 9(1), 18.

Andersen, P., Andersen, J.L., \& Frost, H. (2010). ITQs in Denmark and resource rent gains. Marine Resource Economics, 25, 11-22.

Andrew, N.L., Béné, C., Hall, S.J., Allison, E.H., Heck, S., \& Ratner, B.D. (2007). Diagnosis and management of small-scale fisheries in developing countries. Fish and Fisheries, 8, 227-240. 
Annala, J.H. (1996). New Zealand's ITQ system: Have the first eight years been a success or a failure? Reviews in Fish Biology and Fisheries, 6, 43-62.

Armitage, D., Marschke, M., \& Plummer, R. (2008). Adaptive co-management and the paradox of learning. Global Environmental Change, 18, 86-98.

Barragán Paladines, M.J., \& Chuenpagdee, R. (2015). Governability assessment of the Galapagos Marine Reserve. Maritime Studies, 14, 13.

Barnes, B., \& Bloor, D. (1982). Relativism, rationalism and the sociology of knowledge. In M. Hollis, \& S. Lukes (Eds.), Rationality and relativism (pp. 21-47). Cambridge: MIT Press.

Basurto, X., Gelcich, S., \& Ostrom, E. (2013). The social-ecological system framework as a knowledge classificatory system for benthic small-scale fisheries. Global Environmental Change, 23, 1366-1380.

Bavinck, M., \& Salagrama, V. (2008). Assessing the governability of capture fisheries in the Bay of Bengal - a conceptual enquiry. The Journal of Transdisciplinary Environmental Studies, 7(1), 5.

Bavinck, M., Chuenpagdee R., Jentoft S., \& Kooiman J. (Eds.). (2013). Governability of fisheries: Theory and applications. Dordrecht: Springer.

Bavington, D. (2002). Managerial ecology and its discontents: Exploring the complexities of control, careful use and coping in resource and environmental management.

Environments, 30, 3-21.

Bavington, D. (2010). Managed annihilation: An unnatural history of the Newfoundland cod collapse. Vancouver: UBC Press.

Berger, P.L., \& Luckmann, T. (1966). The social construction of reality. Garden City, NY: Anchor Books.

Berkes, F., Colding, J., \& Folke, C. (Eds.). (2008). Navigating social-ecological systems: Building resilience for complexity and change. Cambridge: Cambridge University Press.

Blaikie, P. (2006). Is small really beautiful? Community-based natural resource management in Malawi and Botswana. World Development, 34, 1942-1957.

Boxer, P., \& Kenny, V. (1990). The economy of discourses: A third order cybernetics? Human Systems Management, 9, 205-224.

Burchell, G., Gordon, C., \& Miller, P. (Eds.). (1991). The Foucault effect: Studies in governmentality. Chicago: The University of Chicago Press.

Carothers, C., \& Chambers, C. (2012). Fisheries privatization and the remaking of fishery systems. Environment and Society, 3, 39-59.

Christie, P., Pollnac, R.B., Oracion, E.G., Sabonsolin, A., Diaz, R., \& Pietri, D. (2009). Back to basics: An empirical study demonstrating the importance of local-level dynamics for the success of tropical marine ecosystem-based management. Coastal Management, 37, 349-373.

Chuenpagdee, R., \& Jentoft, S. (2009). Governability assessment for fisheries and coastal systems: A reality check. Human Ecology, 37, 109-120.

Chuenpagdee, R., \& Jentoft, S. (2013). Assessing governability - What's next. In M.

Bavinck, R. Chuenpagdee, S. Jentoft, \& J. Kooiman (Eds.), Governability of fisheries and aquaculture: Theory and applications (pp. 335-349). Dordrecht: Springer. 
Chuenpagdee, R., \& Jentoft, S. (2015). Exploring challenges in small-scale fisheries governance. In S. Jentoft \& R. Chuenpagdee (Eds.), Interactive governance for smallscale fisheries: Global reflections (pp. 3-16). Cham: Springer.

Chuenpagdee, R., Kooiman, J., \& Pullin, R. (2008). Assessing governability in capture fisheries, aquaculture and coastal zones. Journal of Transdisciplinary Environmental Studies, 7(1), 3.

Cox, M. (2012). Diagnosing institutional fit: A formal perspective. Ecology and Society, 17(4), 54.

Cox, M., Arnold, G., \& Villamayor-Tomas, S. (2010). A review of design principles for community-based natural resource management. Ecology and Society, 15(4), 38.

Cox, M., Villamayor-Tomas, S., \& Arnold, G. (2016). Design principles in commons science: A response to "Ostrom, Hardin and the commons" (Araral). Environmental Science \& Policy, 61, 238-242.

Dean, M. (1999). Governmentality: Power and rule in modern society. London: Sage Publications.

Derkyi, M., Ros-Tonen, M.A.F., Kyereh, B., \& Dietz, T. (2013). Emerging forest regimes and livelihoods in the Tano Offin Forest Reserve, Ghana: Implications for social safeguards. Forest Policy \& Economics, 32, 49-56.

Di Lucia, L. (2013). Too difficult to govern? An assessment of the governability of transport biofuels in the EU. Energy Policy, 63, 81-88.

Duit, A., \& Galaz, V. (2008). Governance and complexity - emerging issues for governance theory. Governance, 21, 311-335.

Folke, C., Hahn, T., Olsson, P., \& Norberg, J. (2005). Adaptive governance of socialecological systems. Annual Review of Environment and Resources, 30, 441-473.

Foucault, M. (1991). Governmentality. In G. Burchell, C. Gordon, \& P. Miller (Eds.), The Foucault effect: Studies in governmentality (pp. 87-104). Chicago: The University of Chicago Press.

Frangoudes, K., \& C. Garineaud. (2015). Governability of kelp forest small-scale harvesting in Iroise Sea, France. In S. Jentoft \& R. Chuenpagdee (Eds.), Interactive governance for small-scale fisheries: Global reflections (pp. 101-115). Cham: Springer.

Geyer, F., \& van der Zouwen, J. (1991). Cybernetics and social science: Theories and research in sociocybernetics. Kybernetes, 20(6), 81-92.

Gill, D.A., Mascia, M.B., Ahmadia, G.N., Glew, L., Lester, S.E., Barnes, M., ... Fox, H.E. (2017). Capacity shortfalls hinder the performance of marine protected areas globally. Nature, 543, 665-669.

Hardin, G. (1968). The tragedy of the commons. Science, 162, 1243-1248.

Hindess, B. (1996). Discourses of power: From Hobbes to Foucault. Oxford: Blackwell Publishers.

Hinkel, J., Cox, M.E., Schlüter, M., Binder, C.R., \& Falk, T. (2015). A diagnostic procedure for applying the social-ecological systems framework in diverse cases. Ecology and Society, 20(1), 32.

Holling, C.S. \& Meffe, G.K. (1996). Command and control and the pathology of natural resource management. Conservation Biology, 10, 328-337. 
Janin, I. (2007). Governability. In M. Bevir (Ed.), Encyclopedia of governance (pp. 363-364). Thousand Oaks: Sage Publications.

Jasanoff, S. (Ed.). (2004). States of knowledge: The co-production of science and social order. London: Routledge.

Jentoft, S. (2007). Limits of governability: Institutional implications for fisheries and coastal governance. Marine Policy, 31, 360-370.

Jentoft, S., \& Chuenpagdee, R. (Eds.). (2015a). Interactive governance for small-scale fisheries: Global reflections. Cham: Springer.

Jentoft, S., \& Chuenpagdee, R. (2015b). Assessing governability of small-scale fisheries. In

S. Jentoft \& R. Chuenpagdee (Eds.), Interactive governance for small-scale fisheries:

Global reflections (pp. 17-35). Cham: Springer.

Jentoft, S., McCay, B.J., \& Wilson, D.C. (1998). Social theory and fisheries management. Marine Policy, 22, 423-436.

Jessop, B. (1997). The governance of complexity and the complexity of governance:

Preliminary remarks on some problems and limits of economic guidance. In A. Amin, \&

J. Hausner (Eds.), Beyond markets and hierarchy: Interactive governance and social complexity (pp. 111-147). Cheltenham: Edward Elgar.

Johnsen, J.P. (2014). Is fisheries governance possible? Fish and Fisheries, 15, 428-444.

Johnsen, J.P. (2017). Creating political spaces at sea - governmentalisation and governability in Norwegian fisheries. Maritime Studies, 16:18.

Johnsen J.P., \& Jentoft S. (2018). Transferable quotas in Norwegian fisheries. In G.M.

Winder (Ed.), Fisheries, quota management and quota transfer (pp. 121-139). Cham:

Springer.

Johnsen, J.P., Holm, P., Sinclair, P.S., \& Bavington, D. (2009). The cyborgization of the fisheries. On attempts to make fisheries management possible Maritime Studies, 7(2), 934.

Johnsen, J.P., Murray, G., \& Neis, B. (2009). North Atlantic fisheries in change - from organic associations to cybernetic organizations. Maritime Studies, 7(2), 55-82.

Johnson, D.S. (2010). Institutional adaptation as a governability problem in fisheries: Patronclient relations in the Junagadh fishery, India. Fish and Fisheries, 11, 264-277.

Johnson, D.S., \& Pálsson, S.K. (2015). Governability and its discontents in the fishery of Lake Winnipeg since the late 1960s: the view from Gimli. In S. Jentoft \& R.

Chuenpagdee (Eds.), Interactive governance for small-scale fisheries: Global reflections (pp. 281-298). Cham: Springer.

Jones, R. (2009). Categories, borders and boundaries. Progress in Human Geography, 33, 174-189.

Kooiman, J. (1993). Modern governance: New government-society interactions. London: Sage Publications.

Kooiman, J. (2008). Exploring the concept of governability. Journal of Comparative Policy Analysis, 10, 171-190.

Kooiman, J., \& Chuenpagdee, R. (2005) Governance and governability. In J. Kooiman, M. Bavinck, S. Jentoft, \& R.S.V. Pullin (Eds.), Fish for life: Interactive governance for fisheries (pp. 325-350). Amsterdam: Amsterdam University Press. 
Kooiman, J., Bavinck, M., Jentoft, S. \& Pullin, R. (Eds.). (2005). Fish for Life: Interactive governance for fisheries. Amsterdam: Amsterdam University Press.

Kooiman, J., Bavinck, M., Chuenpagdee, R., Mahon, R., \& Pullin, R. (2008). Interactive governance and governability: An introduction. Journal of Transdisciplinary Environmental Studies, 7(1), 2.

Latour, B. (1986). The powers of association. In J. Law (Ed.), Power, action and belief: A new sociology of knowledge? (pp. 264-280). London: Routledge \& Kegan Paul.

Lemke, T. (2007) An indigestible meal? Foucault, governmentality and state theory. Distinktion: Journal of Social Theory, 8(2), 43-64.

Li, T.M. (2007). Practices of assemblage and community forest management. Economy and Society, 36, 263-293.

Löf, A. (2016). Locking in and locking out: a critical analysis of the governance of reindeer husbandry in Sweden. Critical Policy Studies, 10, 426-447.

Mayntz, R. (1993). Governing failures and the problem of governability: Some comments on a theoretical paradigm. In J. Kooiman (Ed.), Modern governance: New governmentsociety interactions (pp. 9-20). London: Sage.

McGinnis, M.D., \& Ostrom, E. (2014). Social-ecological system framework: Initial changes and continuing challenges. Ecology and Society, 19(2), 30.

McGoodwin, J. (1990). Crisis in the world's fisheries. Stanford: Stanford University Press.

Morrison, T.H. (2017). Evolving polycentric governance of the Great Barrier Reef. PNAS, 114, E3013-E3021.

Olsson, P., Folke, C., \& Hughes, T.P. (2008). Navigating the transition to ecosystem-based management of the Great Barrier Reef, Australia. PNAS, 105, 9489-9494.

Ostrom, E. (1990). Governing the commons: The evolution of institutions for collective action. Cambridge: Cambridge University Press.

Ostrom, E. (2009). A general framework for analyzing sustainability of social-ecological systems. Science, 325, 419-422.

Ostrom, E., \& Cox, M. (2010). Moving beyond panaceas: A multi-tiered diagnostic approach for social-ecological analysis. Environmental Conservation, 37, 451-463.

Pahl-Wostl, C. (2009). A conceptual framework for analysing adaptive capacity and multilevel learning processes in resource governance regimes. Global Environmental Change, 19, 354-365.

Pelosi, C., Goulard, M., \& Balent, G. (2010). The spatial scale mismatch between ecological processes and agricultural management: Do difficulties come from underlying theoretical frameworks? Agriculture, Ecosystems and Environment, 139, 455-462.

Pinkerton, E., \& Davis, R. (2015). Neoliberalism and the politics of enclosure in North American small-scale fisheries. Marine Policy, 61, 303-312.

Pittman, J. (2016). Governance across the land-sea interface (Unpublished doctoral thesis). University of Waterloo, Canada.

Powell, N.S., Larsen, R.K., \& van Bommel, S. (2014). Meeting the 'Anthropocene' in the context of intractability and complexity: Infusing resilience narratives with intersubjectivity. Resilience, 2(3), 135-150.

Rhodes, R.A.W. (1996). The new governance: Governing without government. Political Studies, XLIV, 652-667. 
Rittel, H.W.J., \& M.M. Webber. (1973). Dilemmas in a general theory of planning. Policy Sciences, 4, 155-169.

Scholtens, J., \& Bavinck, M. (2013). South Indian trawl fisheries - Assessing their governability. In M. Bavinck, R. Chuenpagdee, S. Jentoft, \& J. Kooiman (Eds.), Governability of fisheries and aquaculture: Theory and applications (pp. 177-199). Dordrecht: Springer.

Scott, B. (2004). Second-order cybernetics: An historical introduction. Kybernetes, 33(9/10), $1365-1378$.

Scott, J.C. (1998). Seeing like a state: How certain schemes to improve the human condition have failed. New Haven: Yale University Press.

Song, A.M. (2015a). Towards a governable co-management in South Korean small-scale fisheries: Interactions of institutions and stakeholders' mindset. In S. Jentoft \& R. Chuenpagdee (Eds.), Interactive governance for small-scale fisheries: Global reflections (pp. 687-704). Cham: Springer.

Song, A.M. (2015b). Pawns, pirates or peacemakers: Fishing boats in the inter-Korean maritime boundary dispute and ambivalent governmentality. Political Geography, 48, 6071.

Song, A.M., \& Chuenpagdee, R. (2010). Operationalizing governability: A case study of a Lake Malawi fishery. Fish and Fisheries, 11, 235-249.

Thompson, M. (2012). Foucault, fields of governability, and the population-family-economy nexus in China. History and Theory 51, 42-62.

Yolles, M., \& Fink, G. (2015). A general theory of generic modelling and paradigm shifts: part 2 - cybernetic orders. Kybernetes, 44(2), 299-310.

Young, O. (2002). The institutional dimensions of environmental change: Fit, interplay, and scale. Cambridge: MIT Press. 